\title{
Stability of Sardine Myofibrils during Storage at Various pH Values
}

\author{
Mohamed Kamal, ${ }^{* 1}$ Shugo Watabe, ${ }^{* 1}$ and Kanehisa Hashimoto*1,2 \\ (Received August 10, 1989)
}

\begin{abstract}
The effect of $\mathrm{pH}$ on the denaturation profile of sardine ordinary and dark muscle myofibrils under various storage conditions was investigated by measuring $\mathrm{Mg}^{2+}$-ATPase activity and solubility. Storage at $0^{\circ} \mathrm{C}$ for 2 days gave rise to two activity maxima both in the presence and absence of $\mathrm{Ca}^{2+}$, one at $\mathrm{pH}$ around 7.5 and another at $\mathrm{pH} 9.5$, and the highest Ca-sensitivity at pH 7.5 regardless of muscle type. After 2 days of storage at $-20^{\circ} \mathrm{C}$, the remaining activities were maximal at $\mathrm{pH}$ around 9.5 either in the presence or absence of $\mathrm{Ca}^{2+}$, while extremely low at pH between 5.5 and 7.5 for both myofibrils. When myofibrils were incubated at $35^{\circ} \mathrm{C}$ for $30 \mathrm{~min}, \mathrm{Mg}^{2+}-\mathrm{ATPase}$ activities in the presence and absence of $\mathrm{Ca}^{2+}$ were both increased with the maximum values at $\mathrm{pH}$ $\mathbf{7}$ for ordinary muscle and at pH $\mathbf{7 . 5}$ for dark muscle myofibrils. Ca-sensitivity of ordinary muscle myofibrils almost disappeared while that of dark muscle to some extent remained, especially in alkaline $\mathrm{pH}$ range.

There was no marked change in solubility and SDS-PAGE pattern of soluble protein fraction throughout $\mathrm{pH}$ examined with both myofibrils stored either at 0 or $-20^{\circ} \mathrm{C}$. The solubility of ordinary muscle myofibrils decreased below $40 \%$ at any $\mathrm{pH}$ after incubation at $35^{\circ} \mathrm{C}$ whereas SDSPAGE pattern showed no myosin heavy chain in the soluble protein fraction. The solubility of dark muscle myofibrils also decreased considerably, especially in an alkaline $\mathrm{pH}$ range. This well corresponded to the SDS-PAGE pattern of the soluble protein fraction where less amount of myosin heavy chain was observed at $\mathrm{pH}$ above 7.5.
\end{abstract}

The largest in quantity among canght in Japan is the sardine Sardinops melanosticta. The utilization of this fish as human food is, however, very low. One of the problems facing the effective utilization of sardine may be associated with a rapid loss of protein quality during storage. For improvement of the method to store this unstable fish meat, deeper knowledge seems necessary on the mechanisms underlying denaturation of the muscle proteins. For this purpose, some properties such as composition and thermal denaturation have been investigated on the sardine ordinary and dark muscle proteins. ${ }^{1,2}$ Myofibril, one of the main muscle components has an enzymatic activity to split ATP. Therefore, by measuring this activity during storage, it was hoped to provide a measure of denaturation. In the previous study, we reported the changes in $\mathrm{Ca}^{2+}$-ATPase activity of the sardine ordinary and dark muscle myofibrils during storage at various $\mathrm{pH}$ values and disclosed a significant correlation between storage conditions and denaturation of myofibrillar proteins. ${ }^{3)}$ To evaluate more precisely on the quality of sardine myofibrillar proteins, it seems important to investigate the possible changes in $\mathrm{Mg}^{2+}$-ATPase activity under similar storage conditions where $\mathrm{Ca}^{2+}$-ATPase activity was followed, since the contribution of $\mathrm{Ca}^{2+}$ and $\mathrm{Mg}^{2+}$ to the mechanism of ATP hydrolysis is different. ${ }^{4}{ }^{b}$ ) In addition, $\mathrm{Mg}^{2+}$-ATPase activity is regulated by small changes in a low concentration of $\mathrm{Ca}^{2+}$ through regulatory proteins such as troponin and tropomyosin. ${ }^{\text {) }}$ In association with these strategies, Seki et al. ${ }^{3)}$ reported that $\mathrm{Mg}^{2+}$-ATPase activity in the presence of $\mathrm{Ca}^{2+}$ of carp ordinary myofibrils increased during 30 days of ice storage at pH 8.4 as did $\mathrm{Ca}^{2+}$-ATPase activity, while the activity in the absence of $\mathrm{Ca}^{2+}$ markedly increased in $\mathrm{pH}$ ranges including 5.6, 6.1 and 8.4. Seki et $a .^{8)}$ also reported that sardine ordinary myofibrillar $\mathrm{Ca}^{2+}$, EDTA-, and $\mathrm{Mg}^{2+}$-ATPase activities both in the presence and absence of $\mathrm{Ca}^{2+}$ decreased considereably during 10 days of ice storage when isolated myofibrils were stored at $\mathrm{pH}$ 6, whereas little change occurred at $\mathrm{pH}$ 7. As for frozen storage, a number of papers have been

*1 Laboratory of Marine Biochemistry, Faculty of Agriculture, The University of Tokyo, Bunkyo, Tokyo 113, Japan (Md. Kamal，溜部終五，橋本周久：東京大学農学部水産化学研究室).

*2 Present address: Food Science Laboratory, Faculty of Education, Ibaraki University, Mito, Ibaraki 310, Japan（現所属：茨城大学教育学部食物学研究室). 
published on fish myosin, actomyosin and myofibrils dealing with changes in reduced viscosity, ${ }^{9}$ ) active $\mathrm{SH}$ groups, ${ }^{10)}$ and $\mathrm{Ca}^{2+}$-ATPase activity. ${ }^{11-13)}$ However very little is known on changes in $\mathrm{Mg}^{2+}$-ATPase activity of fish myofibrillar proteins during frozen storage. Furthermore, sardine has a high content of superficial dark muscle, the properties of which are markedly different from those of the ordinary muscle. ${ }^{14}$

In this situation, $\mathrm{Mg}^{2+}-\mathrm{ATPase}$ activity of the sardine's ordinary and dark muscle myofibrils was monitored during various types of storage. Solubility changes were also followed for both myofibrils to assess the denaturation profible more clearly.

\section{Materials and Methods}

\section{Materials}

Live specimens of sardine Sardinops melanosticta (average body weight, $69 \mathrm{~g}$ ) were captured off Misaki, Kanagawa Prefecture. Immediately after each catch, specimens were killed by decaptitation and transported to the laboratory in ice. The ordinary and dark myotomal muscles were excised at $4^{\circ} \mathrm{C}$, taking care to minimize cross-contamination of fiber types. The ordinary muscle was dissected from the dorsal part, while the dark muscle from the whole trunk under the lateral line. Some sardine specimens were stored at $-80^{\circ} \mathrm{C}$ in polyethylene bags for preparation of myofibrils when needed.

\section{Preparation of Myofibrils}

Myofibrils were prepared from ordinary and dark muscles immediately after excision according to Perry and Grey ${ }^{15)}$ in the presence of $0.1 \mathrm{~mm}$ dithiothreitol (DTT) throughout as reported previously. ${ }^{3)}$ Well washed myofibrils were suspended in $39 \mathrm{~mm}$ borate buffer ( $\mathrm{pH} 7.1$ ) containing $0.1 \mathrm{M} \mathrm{KCl}$ and $0.1 \mathrm{mM}$ DTT at a concentration of $10-15 \mathrm{mg} / \mathrm{m} l$.

Storage Conditions of Myofibrils and $\mathrm{Mg}^{2+}$ ATPase Assay

Myofibrils $(5 \mathrm{mg} / \mathrm{m} l$ ) were stored in $1 \mathrm{~m} l$ of $0.1 \mathrm{M} \mathrm{KCl}$ plus $10 \mathrm{~mm}$ Tris-maleate ( $\mathrm{pH} \mathrm{5.5-8.0)}$ or glycine- $\mathrm{KOH}$ ( $\mathrm{pH} 8.5-9.6)$. Myofibril samples thus prepared were stored at $0^{\circ} \mathrm{C}$ for 2 days, $-20^{\circ} \mathrm{C}$ for 2 days, or incubated at $35^{\circ} \mathrm{C}$ for $30 \mathrm{~min}$. After storage, $\mathrm{Mg}^{2+}$-ATPase activity was assayed at $25^{\circ} \mathrm{C}$ as reported previously ${ }^{83}$ in $40 \mathrm{~mm}$ Trismaleate ( $\mathrm{pH} \mathrm{7.0)}$ containing $5 \mathrm{mM} \mathrm{MgCl}_{2}, 50 \mathrm{~mm}$ $\mathrm{KCl}, 1 \mathrm{~mm}$ ATP and $0.5 \mathrm{mg} / \mathrm{m} /$ of myofibril with either $0.25 \mathrm{mM} \mathrm{CaCl}$ or $1 \mathrm{~mm}$ ethylene glycol bis ( $\beta$-aminoethyl ether) $N, N, N^{\prime}, N^{\prime}$-tetraacetic acid (EGTA) in a final volume of $10 \mathrm{ml}$. The $\mathrm{pH}$ of the reaction mixture was around 7 during ATPase assay. Inorganic phosphate libreated was analyzed by the method of Fiske and SubbaRow. ${ }^{19)}$

\section{Solubility Test}

Myofibrils suspension $(5 \mathrm{mg} / \mathrm{m} l)$ in $2 \mathrm{ml}$ of $0.1 \mathrm{M} \mathrm{KCl}$ plus $10 \mathrm{~mm}$ Tris-maleate (pH 5.5-8.0) or glycine- $\mathrm{KOH}(\mathrm{pH} 8.5-9.4)$ was stored essentially under the same conditions as before. After storage, each tube was taken out, thawed or cooled at $4^{\circ} \mathrm{C}$ and homogenized with $2 \mathrm{ml}$ of $1 \mathrm{M}$ $\mathrm{KCl}$ plus $100 \mathrm{~mm}$ phosphate buffer ( $\mathrm{pH} 7.0$ ) using a Polytron PTA $7 \mathrm{~K}$. The homogenate was centrifuged for $30 \mathrm{~min}$ at $900 \times \mathrm{g}$ and $4^{\circ} \mathrm{C}$ and protein content in the supernatant was determined by the biuret method. ${ }^{17}$ )

\section{Sodium Dodecyl Sulfate-Polyacrylamide Gel Elec-} trophoresis (SDS-PAGE)

SDS-PAGE was performed according to Laem$\mathrm{mli}^{18)}$ using $7.5-20 \%$ gradient slab gels containing $0.1 \%$ SDS. A $100 \mu l$ of soluble protein fraction was mixed with $100 \mu l$ of distilled water, $200 \mu l$ of $0.125 \mathrm{M}$ Tris- $\mathrm{HCl}$ (pH 6.8) containing $50 \%$ glycerol and $1 \% \mathrm{SDS}$, and $40 \mu \mathrm{l}$ of 2-mercaptoethanol, then treated at $100^{\circ} \mathrm{C}$ for about one min. A $50 \mu l$ of the sample thus treated was loaded on the gel. After the run, gels were stained with Coomassie brillant blue R-250.

\section{Results}

Myofibrillar $\mathrm{Mg}^{2+}$-ATPase Activity of the Ordinary and Dark Muscles

$\mathrm{Mg}^{2+}$-ATPase activity was assayed in the presence of activating $(0.25 \mathrm{mM} \mathrm{CaCl})$ and relaxing ( $1 \mathrm{~mm}$ EGTA) buffers after storage at various temperatures and $\mathrm{pH}$ values. After ice storage, the activity curve of the sardine ordinary muscle myofibrils in the presence of $\mathrm{Ca}^{2+}$ showed a relatively sharp peak at $\mathrm{pH}$ around 9 and a small dull one at around 7.5 with activities of 0.45 and $0.42 \mu \mathrm{mol} \mathrm{Pi} / \mathrm{min} \cdot \mathrm{mg}$, respectively (Fig. 1A). ATPase activity measured in the absence of $\mathrm{Ca}^{2+}$ similarly showed two maxima, one at $\mathrm{pH}$ around $6.5(0.18 \mu \mathrm{mol} \mathrm{Pi} / \mathrm{min} \cdot \mathrm{mg})$ and another around $9(0.19 \mu \mathrm{mol} \mathrm{Pi} / \mathrm{min} \cdot \mathrm{mg})$. The activity was lowest at pH 5.5 in both buffers as far as the present $\mathrm{pH}$ range is concerned. The maximum $\mathrm{Ca}$ sensitivity of $67 \%$ was observed at $\mathrm{pH}$ around 7.5. In order to determine whether ice storage 


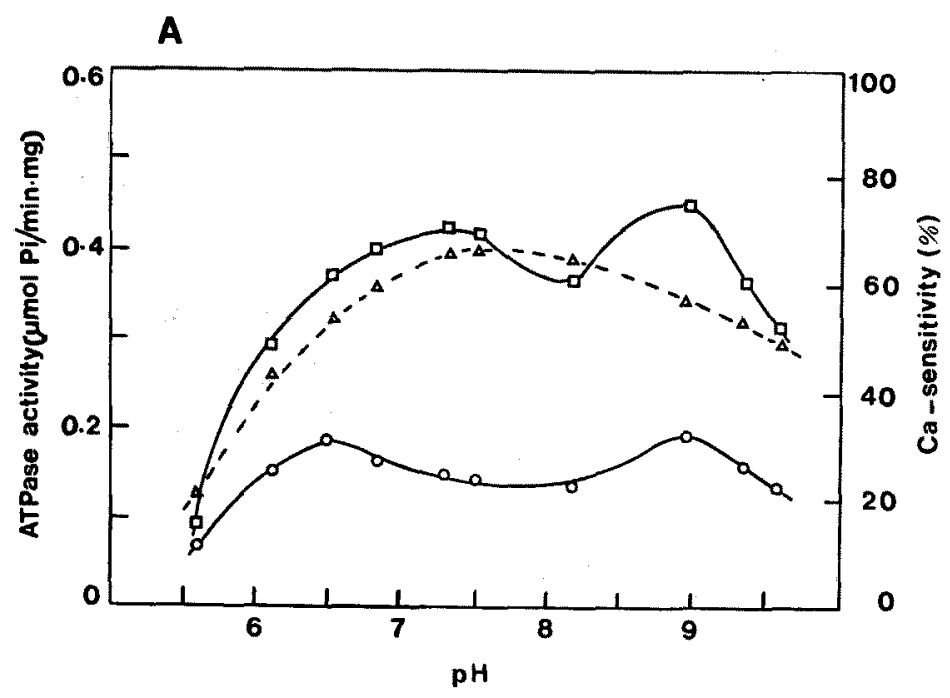

B

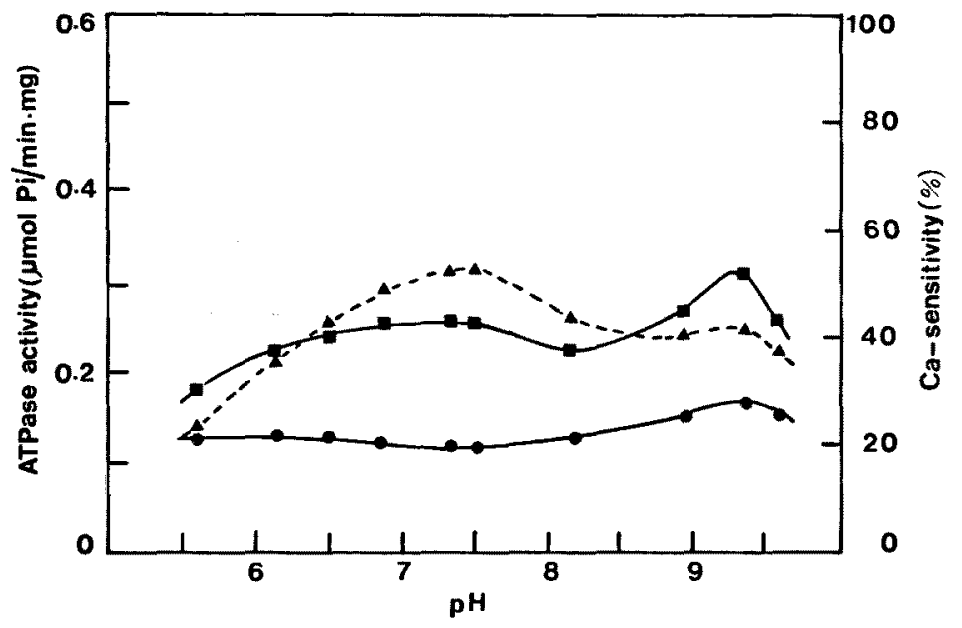

Fig. 1. Influence of $\mathrm{pH}$ on $\mathrm{Mg}^{2+}$-ATPase activity and Ca-sensitivity of sardine ordinary (A) and dark (B) muscle myofibrils after storage at $0^{\circ} \mathrm{C}$ for 2 days. $\mathrm{Mg}^{2+}$-ATPase activity of ordinary (A) and dark (B) muscle myosfibrils was measured in the presence of $0.25 \mathrm{mM} \mathrm{CaCl}_{2}(\square, \square ; \mathrm{I})$ and $1 \mathrm{mM}$ EGTA $(\mathrm{O}, \bullet$;I) and Ca-sensitivity was calculated as $(\mathrm{I}-\mathrm{II}) \times 100 / \mathrm{I}(\triangle, \Lambda)$.

has any effect on the changes in $\mathbf{M g}^{\mathbf{2}}$-ATPase activity, a preliminary experiment was conducted by storing sardine ordinary myofibrils at $0^{\circ} \mathrm{C}$ and pH 7. A very little decrease in activity was evident after 2 days of storage in $\mathrm{Ca}^{2+}$-activating buffer while EGTA-modified $\mathrm{Mg}^{2+}$-ATPase activity remained essentially unchanged (data not shown). Ca-sensitivity was $70-75 \%$ immediately after preparation of myofibrils at $\mathrm{pH} 7$.

After ice storage for 2 days, dark muscle myofibrils showed a pH-remaining activity pattern almost similar to that of ordinary muscle myofibrils (Fig. 1B). Unlike ordinary muscle myofibrils, dark muscle myofibrils showed $\mathrm{Mg}^{2+}$-ATPase activities both in the presence and absence of $\mathrm{Ca}^{2+}$ comparatively stable in the acidic $\mathrm{pH}$ region. The maximum value was observed at $\mathrm{pH} 9.3$ both in activating and relaxing buffers with 0.32 and 0.17 $\mu \mathrm{mol} \mathrm{Pi} / \mathrm{min} \cdot \mathrm{mg}$, respectively. The highest remaining Ca-sensitivity was $53 \%$ at $\mathrm{pH} 7.5, \mathrm{Mg}^{2+}$. ATPase activities in the presence and absence of $\mathrm{Ca}^{2+}$ were 0.28 and $0.13 \mu \mathrm{mol} \mathrm{Pi} / \mathrm{min} \cdot \mathrm{mg}$, respectively, immediately after preparation at $\mathrm{pH} 7$, resulting in Ca-sensitivity of $54 \%$.

Frozen storage resulted in aggregation of ordinary muscle myofibrils at any $\mathrm{pH}$. When myo- 

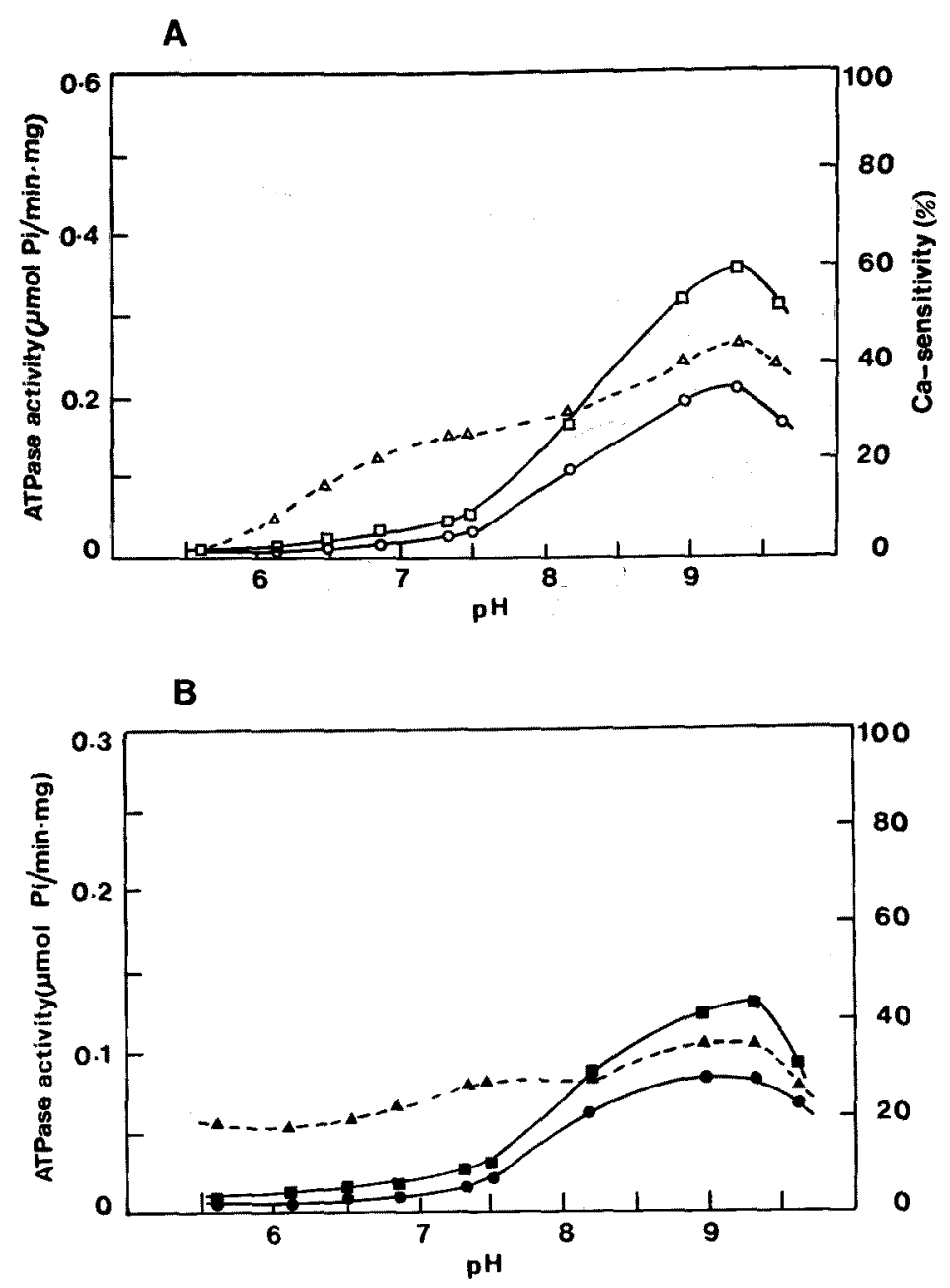

Fig. 2. Infiuence of $\mathrm{pH}$ on $\mathrm{Mg}^{2+}$-ATPase activity and $\mathrm{Ca}$-sensitivity of sardine ordinary (A) and dark (B) muscle myofibrils after storage at $-20^{\circ} \mathrm{C}$ for 2 days. Refer to the legend in Fig. 1 for symbols and further details.

fibrillar $\mathrm{Mg}^{2+}$-ATPase activity was assayed, the remaining maximum was obtained at $\mathrm{pH} 9.3$ in both activating and relaxing buffers with 0.36 and $0.21 \mu \mathrm{mol} \mathrm{Pi} / \mathrm{min} \cdot \mathrm{mg}$, respectively, although it was hardly observed at pH lower than 7.5 (Fig. 2A). Ca-sensitivity was relatively high at an alkaline $\mathrm{pH}$ with the maximum of $43 \%$ at $\mathrm{pH} 9.3$.

Dark muscle myofibrils aggregated after frozen storage. When they were assayed for $\mathrm{Mg}^{2+}$ ATPase activity, the remaining maximum was observed again at $\mathrm{pH} 9.3$ both in the presence and absence of $\mathrm{Ca}^{2+}$ with 0.13 and $0.09 \mu \mathrm{mol} \mathrm{Pi} / \mathrm{min}$. $\mathrm{mg}$, respectively (Fig. 2B). The pH-remaining activity pattern was quite similar to that observed for ordinary muscle myofibrils (Fig. 2A), although the specific activity of dark muscle myofibrils was much lower. Ca-sensitivity maxiumum was $35 \%$ at pH 9.

When sardine ordinary myofibrils were incubated at $35^{\circ} \mathrm{C}$ for $30 \mathrm{~min}, \mathrm{Mg}^{2+}$-ATPase activities in the presence and absence of $\mathrm{Ca}^{2+}$ were markedly increased and their maxima were observed both at around $\mathrm{pH} 7$ with 0.70 and $0.63 \mu \mathrm{mol} \mathrm{Pi} / \mathrm{min} \cdot \mathrm{mg}$, respectively, as shown in Fig. $3 \mathrm{~A}$ (see the specific activity after ice storage at neutral pH, Fig. 1A, as a control). The curve gradually declined with a subsequent rise of $\mathrm{pH}$ over 7 and rapidly above $\mathrm{pH}$ 9. Both activities decreased rapidly at $\mathrm{pH}$ below 6.5 and almost disappeared at $\mathrm{pH}$ 5.5. On the other hand, Ca-sensitivity almost disappeared irrespective of $\mathrm{pH}$, after preparation of myofibrils at pH 7 (data not shown).

When dark muscle myofibrils were incubated at $35^{\circ} \mathrm{C}, \mathrm{Mg}^{2+}$-ATPase in activating and relaxing 

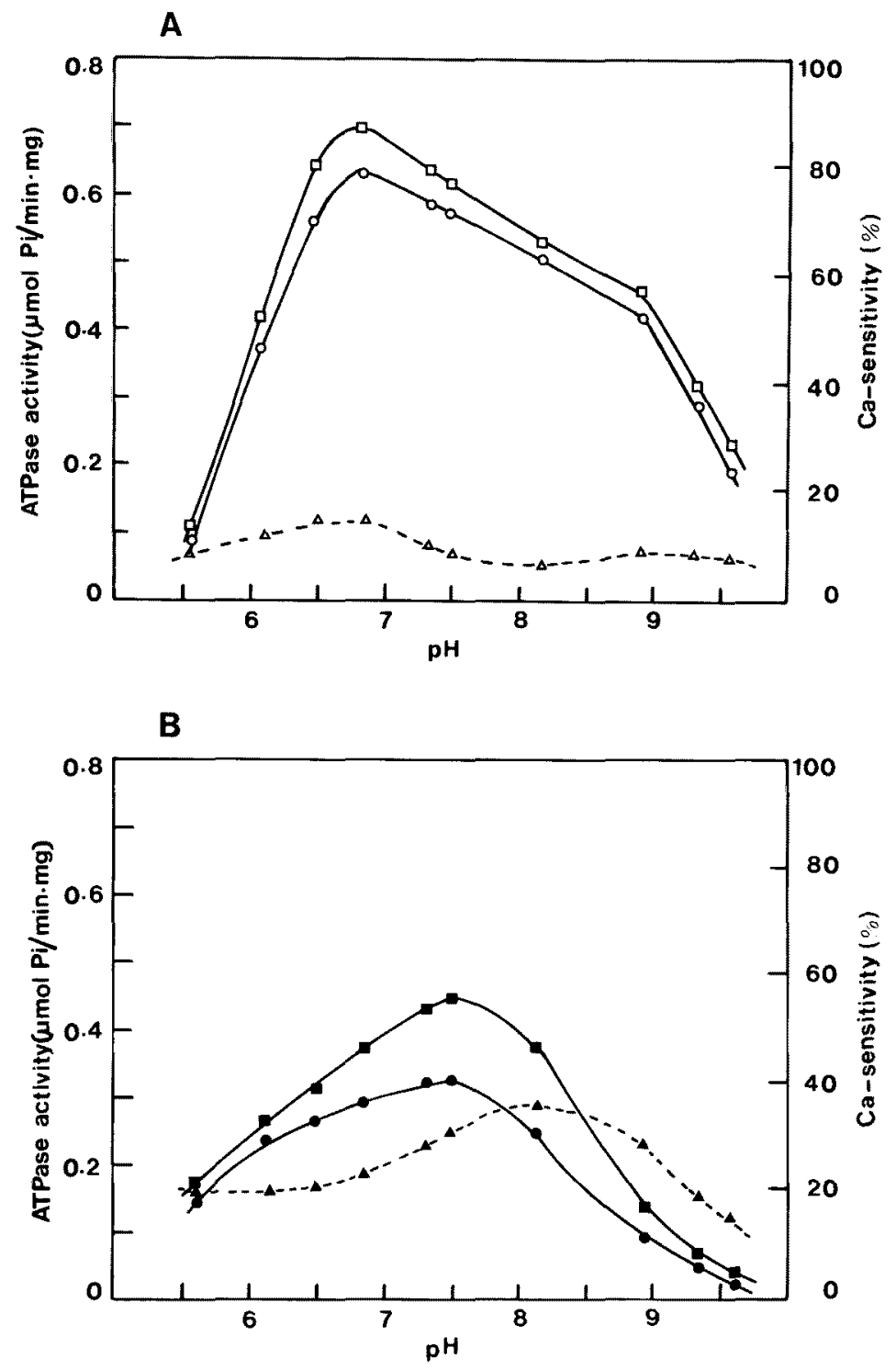

Fig. 3. Influence of $\mathrm{pH}$ on $\mathrm{Mg}^{2+}$-ATPase activity and Ca-sensitivity of sardine myofibrils after incubation at $35^{\circ} \mathrm{C}$ for $30 \mathrm{~min}$. Refer to the legend in Fig. 1 for symbols and further details.

buffers showed the activity maximum both at $\mathrm{pH}$ around 7.5 with 0.46 and $0.32 \mu \mathrm{mol} \mathrm{Pi} / \mathrm{min} \cdot \mathrm{mg}$, respectively (Fig. 3B). Unlike ordinary muscle myofibrils, dark muscle counterparts showed great decrease in activity at alkaline $\mathrm{pH}$. Casensitivity was considerably lower at any $\mathrm{pH}$, but was less affected than that of ordinary muscle myofibrils, particularly in the $\mathrm{pH}$ range between 7.5 and 9.

\section{Solubility and SDS-PAGE of Soluble Protein Fraction}

To examine the effect of $\mathrm{pH}$ on the solubility of sardine myofibrillar proteins, storage experiments were carried out at various pHs ranging from 5.8 to 9.4. Fig. 4 shows changes in solubility and SDS-PAGE pattern of soluble protein fraction after ice storage for 2 days. The solubility of dark muscle myofibrils was considerably high at any $\mathrm{pH}$ compared to that of ordinary muscle myofibrils. The maximum value was $84 \%$ with ordinary muscle myofibrils at $\mathrm{pH} 7.0$ while $95 \%$ at $\mathrm{pH}$ around 7.5 with dark muscle myofibrils. There was no marked change in electrophoretic pattern for both ordinary and dark myofibrils throughout pH examined. 


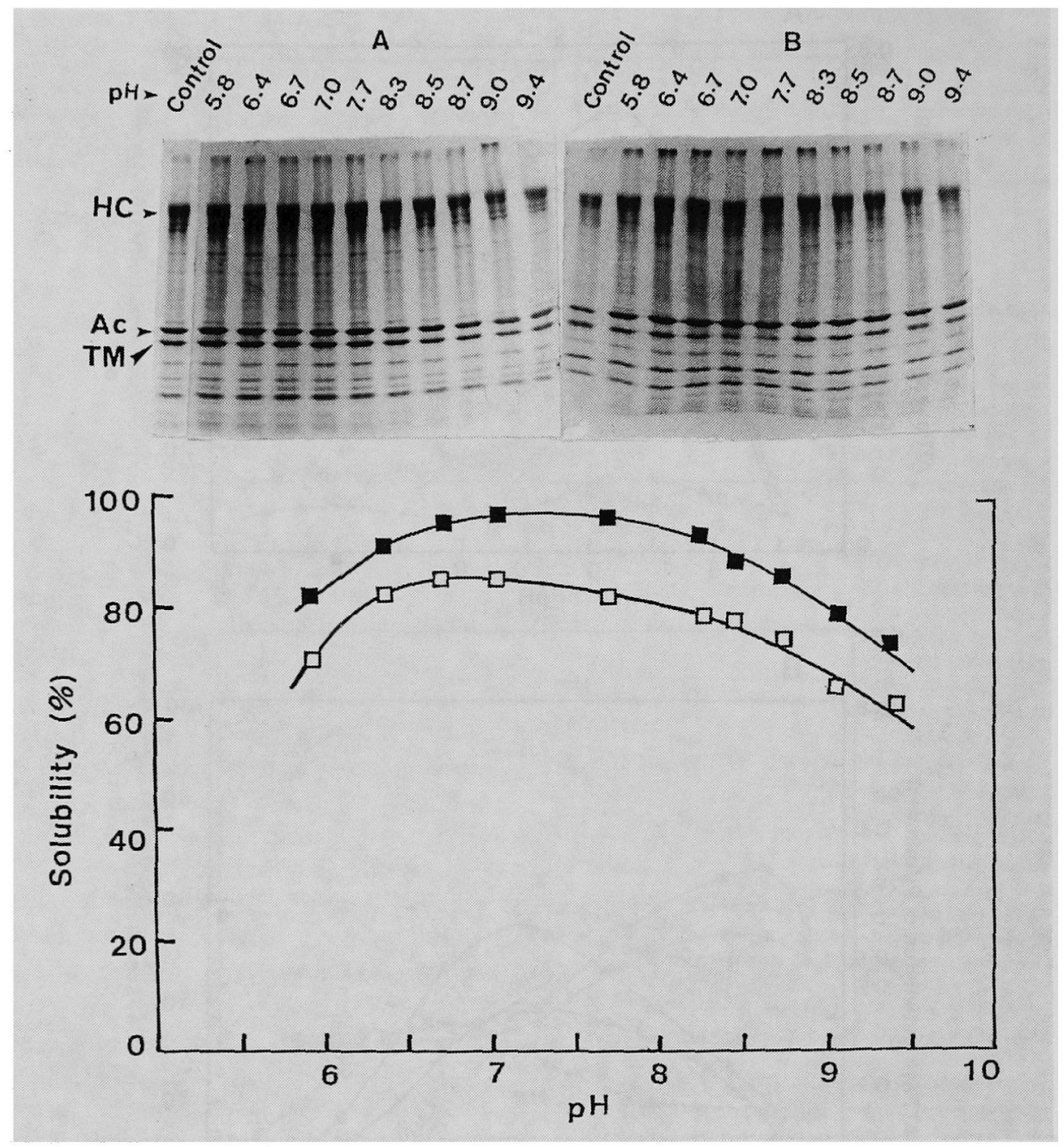

Fig. 4. Influence of $\mathrm{pH}$ on the solubility and SDS-PAGE pattern of soluble protein fraction of sardine myofibrils after storage at $0^{\circ} \mathrm{C}$ for 2 days. Sardine ordinary ( $\square$ ) and dark ( $\square$ ) muscle myofibrils were solubilized in $0.5 \mathrm{M} \mathrm{KCl}$ plus $50 \mathrm{~mm}$ phosphate buffer $(\mathrm{pH} 7)$, then soluble protein fraction of ordinary (A) and dark (B) muscle myofibrils were subjected to SDS-PAGE (top photographs).

As shown in Fig. 5, both sardine ordinary and dark muscle myofibrils showed the maximum solubility at pH 7.7 with $79 \%$ and $83 \%$, respectively, after 2 days of frozen storage at $-20^{\circ} \mathrm{C}$. There was no apparent change in electrophoretic pattern of soluble protein fractions from ordinary and dark muscle myofibrils at any $\mathrm{pH}$.

When incubated at $35^{\circ} \mathrm{C}$ for $30 \mathrm{~min}$, ordinary myofibrillar proteins decreased in solubility below $40 \%$ irrespective of $\mathrm{pH}$ as shown in Fig. 6. Their solubility was higher than $85 \%$ at $\mathrm{pH} 7$ immediately after preparation. In dark muscle myofibrils, the pattern of changes in solubility was varied depending on $\mathrm{pH}$. The solubility was markedly high in the acidic $\mathrm{pH}$ region with the maximum of $68 \%$ at $\mathrm{pH} 6.7$, though still much lower than $98 \%$ of the control immediately after preparation. It was decreased with a subsequent rise of $\mathrm{pH}$.

The top photographs in Fig. 6 show the changes in electrophoretic patterns of the soluble fractions after incubation at $35^{\circ} \mathrm{C}$ for $30 \mathrm{~min}$. The ordinary muscle soluble protein fraction exhibited hardly any myosin heavy chain even after such a mild heat reatment. Actin band also became faint. The main protein band was probably that of tropomyosin which was dissociated from aggregated actomyosin. On the other hand, myosin heavy chain was clearly observed in the soluble protein 


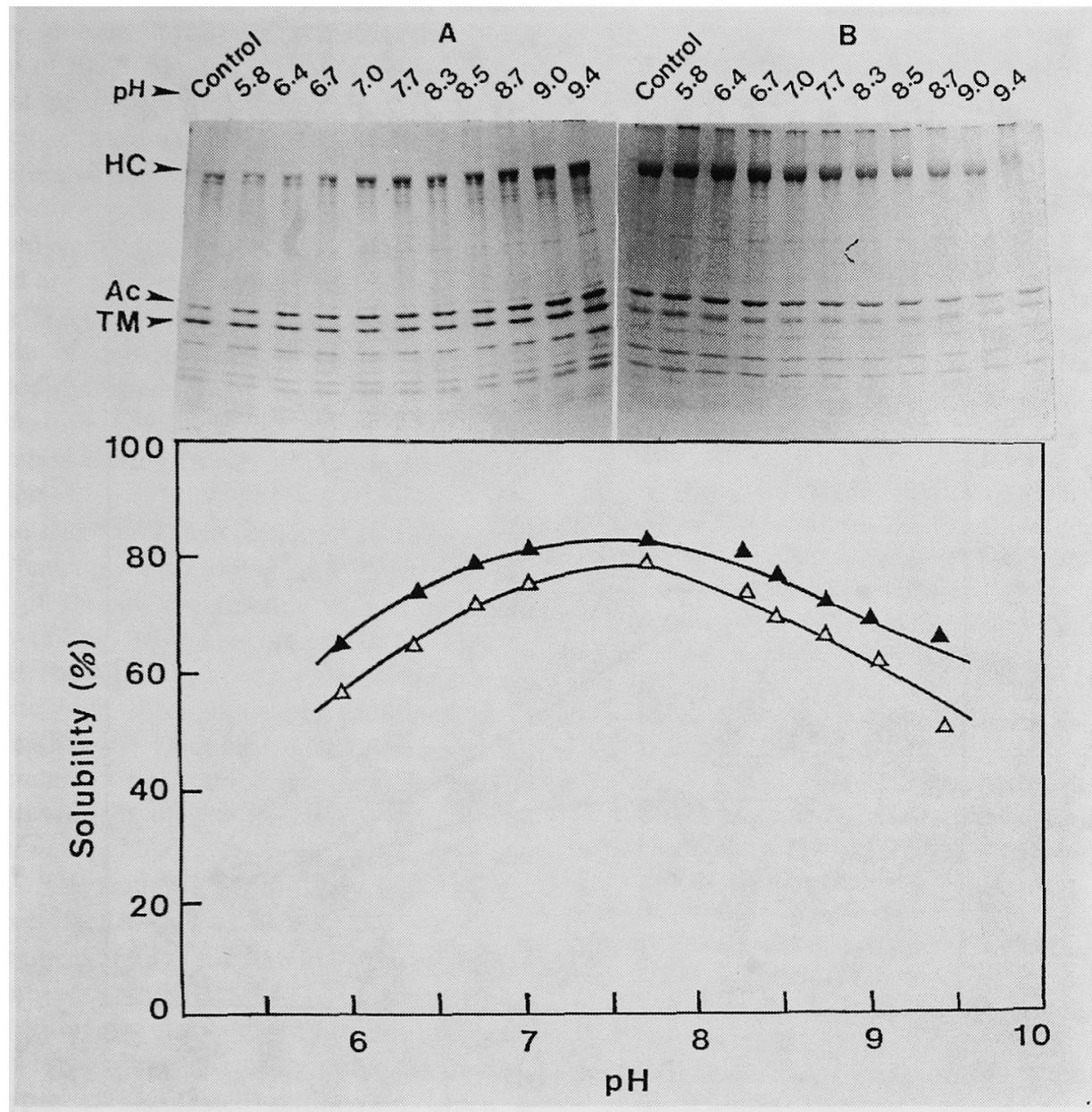

Fig. 5. Influence of $\mathrm{pH}$ on the solublity and SDS-PAGE pattern of soluble protein fraction of sardine ordinary $(\mathrm{A}, \triangle)$ and dark $(\mathbf{B}, \mathbf{\Delta})$ muscle myofibrils after storage at $-20^{\circ} \mathrm{C}$ for 2 days. Refer to the legend in Fig. 4 for further details.

fraction of dark muscle myofibrils, especially in the acidic $\mathrm{pH}$ region.

\section{Discussion}

Changes in $\mathrm{Mg}^{2+}$-ATPase activity and solubility of sardine ordinary and dark muscle myofibrils during storage at various $\mathrm{pH}$ values have well been demonstrated. At $0^{\circ} \mathrm{C}$, both sardine myofibrils exhibited the maximum remaining ATPase activity at alkaline $\mathrm{pH}$ around 9 both in the presence and absence of $\mathrm{Ca}^{2+}$. Evidence has been presented elsewhere ${ }^{7)}$ that changes in ATPase activity and loss of Ca-sensitivity of myofibrils during ice storage, especially in an alkaline medium might be due to modification of actin-myosin interaction by the oxidation of the thiol groups of myosin moiety.
After frozen storage, both myofibrils showed the maximum remaining activity at alkaline $\mathrm{pH}$, the activity being hardly seen at acidic and neutral $\mathrm{pH}$ in any $\mathrm{Mg}^{2+}$-ATPase assay system. Unfortunately, the present phenomena were not clearly understood, thus any discussion on it must be at best speculative. It should be, however, emphasized that the hydrogen bond probably increased during frozen storage, and an interaction between hydrophobic and hydrogen bonds resulted in aggregation of myofibrillar proteins as found by Buttkus $^{10)}$ with rabbit and trout myosins. This might be attributable to structural changes in myofibrillar proteins which would result in a decreased affinity between actin and myosin as observed by Ohnishi et al. ${ }^{1 \theta)}$ with carp ordinary muscle actomyosin during frozen storage. As a result of conformational changes, the interaction 


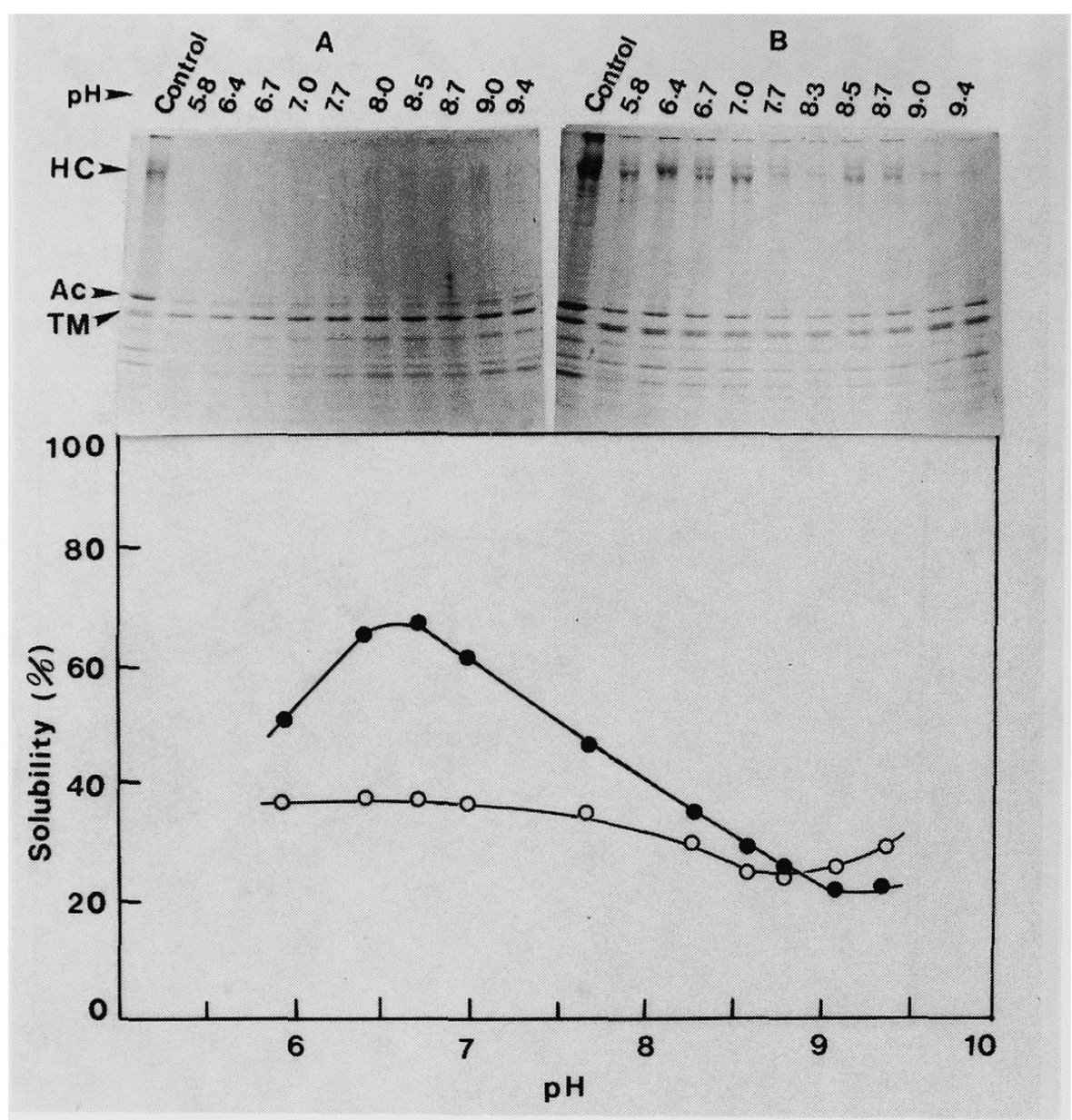

Fig. 6. Influence of $\mathrm{pH}$ on the solubility and SDS-PAGE pattern of soluble protein fraction of sardine ordinary $(\mathrm{A}, \mathrm{O})$ and dark $(\mathrm{B}, \bullet)$ muscle myofibrils after incubation at $35^{\circ} \mathrm{C}$ for $30 \mathrm{~min}$. Refer to the legend in Fig. 4 for further details.

of myosin with actin might be reduced. It is therefore likely that the decreased activity in both $\mathrm{Mg}^{2+}$ assay systems at acidic and neutral $\mathrm{pH}$ with ordinary and dark muscle myofibrils was due to an increased proportion of ATPase activity catalyzed by myosin alone. However, a comparatively high ATPase activity at an alkaline $\mathrm{pH}$ might be argued that polymerization reaction of proteins is labile and partially reversible where dissociation readily occurs at moderately high $\mathrm{pH}$ due to the net negative charge of macromolecules. ${ }^{20)}$

The increase of $\mathrm{Mg}^{2+}$-ATPase activity and loss of Ca-sensitivity with both myofibrils either in the presence or absence of $\mathrm{Ca}^{2+}$ after a mild heat treatment could be due to conformational changes occurring in regulatory proteins of troponintropomyosin complex. It would seem then, at least in the case of sardine muscle, that the $\mathrm{Ca}^{2+}$ regulatory system does not function well at temperatures above the physiological range as found by Fuchs et al..$^{21)}$ at $30^{\circ} \mathrm{C}$ with frog actomyosin and $40-45^{\circ} \mathrm{C}$ with rabbit skeletal actomyosin. Taguchi et al. ${ }^{22)}$ reported that the increase of $\mathrm{Mg}^{2+}$-ATPase activity with flying fish actomyosin during $50 \mathrm{~min}$ incubation at $35^{\circ} \mathrm{C}$ and $\mathrm{pH} 7$ could be due to interaction between myosin and actin during thermal treatment.

Four more general observations can be made concerning the changes in $\mathrm{Mg}^{2+}$-ATPase activity during storage at various $\mathrm{pH}$ values. At first, the myofibrillar ATPase activity of ordinary muscle was quite higher than that of dark muscle. This agreed with those reported for other fishes. ${ }^{23-25)}$ Secondly, the changes in myofibrillar ATPase activity of both muscles at 35 and $-20^{\circ} \mathrm{C}$ were prominent compared to those of ice storage. 
Thirdly, the low activity at $\mathrm{pH} 5.5$ in sardine ordinary muscle myofibrils revealed the direct function of pH. Finally, it should be noted that the most prominent differences exist in $\mathrm{pH}$ dependency between remaining $\mathrm{Ca}^{2+}{ }^{3)}$ and $\mathrm{Mg}^{2+}$ ATPase activities for both sardine ordinary and dark myofibrils when stored at $-20^{\circ} \mathrm{C}$. The maximum remaining $\mathrm{Ca}^{2+}$-ATPase activity was observed at a pH level around 7.5, while extremely low $\mathrm{Mg}^{2+}$-ATPase activity in this $\mathrm{pH}$ region irrespective of muscle type. Therefore, it can be concluded that myofibrillar $\mathbf{M g}^{\mathrm{q}+}$-ATPase activity is a sensitive parameter to know myofibrillar denaturation during frozen storage in the neutral $\mathrm{pH}$ region.

Unlike $\mathrm{Mg}^{2+}$-ATPase activity, there was no marked change in solubility and electrophoretic pattern of the soluble fraction at any $\mathrm{pH}$ with both myofibrils stored either at 0 or $-20^{\circ} \mathrm{C}$. Although the solubility after ice and forzen storage was quite high throughout $\mathrm{pH}$ examined, it is probable that the solubility might decrease with the extended storage period as found by Seki et $a .^{7)}$ with carp myofibrils during ice storage and Oguni et $a{ }^{20)}$ with carp actomyosin during frozen storage. The solubility in ordinary muscle myofibrils decreased to below $40 \%$ at any $\mathrm{pH}$ during heat treatment at $35^{\circ} \mathrm{C}$ for $30 \mathrm{~min}$. The result was consistent with the SDS-PAGE pattern which showed no myosin heavy chain in soluble protein fraction throughout the $\mathrm{pH}$ range examined. Some types of aggregated actomyosin which is not salt-soluble would rather activate $\mathrm{Mg}^{2+}$ ATPase activity. The solubility of dark muscle myofibrils also considerably decreased but remained much higher in weakly acidic and neutral $\mathrm{pH}$ ranges than in alkaline range. This well corresponded to SDS-PAGE patterns of the soluble protein fraction where less amount of myosin heavy chain was observed at $\mathrm{pH}$ above 7.5.

\section{Acknowledgments}

We are grateful to the staff of Kanagawa Prefectural Fisheries Experimental Station for their help in collecting sardine specimens.

\section{References}

1) S. Watabe, K. Kanna, and T. Suzuki: Nippon Suisan Gakkaishi, 43, 1353 (1977).

2) K. Hashimoto, S. Watabe, M. Kono, and K. Shiro: Nippon Suisan Gakkaishi, 45, 1435-1441 (1979).

3) S. Watabe, M. Kamal, and K. Hashimoto: Nippon Suisan Gakkaishi, 55, 703-707 (1989).

4) M. Burke, E. Reisler, and W. F. Harrington: Proc. Nat. Acad. Sci., 70, 3793-3796 (1973).

5) E. Reisler, M. Burke, and W. F. Harrington: Biochemistry, 13, 2014-2022 (1974).

6) S. Ebashi and M. Endo: Prog. Biophys. Mol. Biol., 18, 123 (1968).

7) N. Seki, M. Ikeda, and N. Narita: Nippon Suisan Gakkaishi, 45, 791-799 (1979).

8) N. Seki, Y. Oogane, and T. Watanabe: Nippon Suisan Gakkaishi, 46, 607-615 (1980).

9) S. Noguchi and J. J. Matsumoto: Nippon Suisan Gakkaishi, 45, 1078-1087 (1970).

10) H. Buttkus: J. Food Sci., 35, 558-562 (1970).

11) K. Arai and R. Takashi: Nippon Suisan Gakkaishi, 39, 533-541 (1973).

12) Y. Fukuda, Z. Tarakita, M. Kawamura, K. Kakehata, and K. Arai: Nippon Suisan Gakkaishi, 48, 1627-1632 (1982).

13) Y. Fukuda, Z. Tarakita, and K. Arai: Nippon Suisan Gakkaishi, 50, 845-852 (1984).

14) T. Suzuki and S. Watabe: Food Rev. Internat., 2, 271-307 (1986-87).

15) S. V. Perry and T. C. Grey: Biochem. J., 64, 184-192 (1956).

16) C. H. Fiske and Y. SubbaRow: J. Biol. Chem., 66, 375-400 (1925).

17) A. G. Gornall, C. J. Bardawill, and M. M. David: J. Biol. Chem., 177, 751-766 (1949).

18) U. K. Laemmli: Nature, 227, 680-685 (1970).

19) M. Ohnishi, T. Tsuchiya, and J. J. Matsumoto: Nippon Suisan Gakkaishi, 44, 27-37 (1978).

20) D. W. Frederiksen and A. Holtzer: Biochemist$r y$, 7, 3953-3949 (1968).

21) F. Fuchs, D. J. Hartshorne, and E. M. Barns: Comp. Biochem. Physiol., 51B, 165-170 (1974).

22) T. Taguchi, M. Tanaka, Y. Nagashima, and K. Amano: J. Food Sci., 51, 1407-1410 (1986).

23) S. Watabe, J. Maruyama, and K. Hashimoto: Nippon Suisan Gakkaishi, 49, 655 (1983).

24) I. A. Johnston, N. Frearson, and G. Goldspink: Experientia, 28, 713-714 (1972).

25) I. A. Johnston and B. Tota: Comp. Biochem. Physiol, 49B, 367-373 (1974).

26) M. Oguni, T. Kubo, and J. J. Matsumoto: Nippon Suisan Gakkaishi, 41, 1113-1123 (1975).

Nippon Suisan Gakkaishi : Formerly Bull. Japan. Soc. Sci. Fish. 